\title{
PERANAN PERPUSTAKAAN SEKOLAH DALAM MENINGKATKAN BUDAYA GEMAR MEMBACA
}

\author{
Gallint Rahadian ${ }^{1}$, Rohanda ${ }^{2}$, Rully Khairul Anwar ${ }^{3}$ \\ ${ }^{1,2,3}$ Program Studi Ilmu Perpustakaan Fikom Unpad \\ ${ }^{1}$ rahadiangallint@yahoo.co.id, ${ }^{2}$ rohanda@unpad.ac.id, ${ }^{3}$ rully.khairul@unpad.ac.id
}

\begin{abstract}
This script describes the results of the research entitled "the role of school libraries in attempt to increase the cultural habits of reading" Madrasah Aliyah grade students in Yapinda Nurul H uda)", This script aims to determine the role of the library consists of four components, librarian, collection, management of the library, and the interior to increasing the reading habits students of Madrasah Aliyah in Yapinda Nurul Huda). This study used a descriptive method where the researcher distributed the questionnaires, interviews, observa- tion and study of literature. The results of the study can be said that the librarian in the library Yapinda Nurul Huda has a role in promoting a culture habits of reading students, the collection at the library Yapinda Nurul Huda has a role in promoting a culture fond of reading students, and library mana- gement in libraries Yapinda Nurul Huda has a role in promoting a culture fond of reading students, and libraries in the library layout Yapinda Nurul Huda have a role in improving students' reading culture likes.
\end{abstract}

Keywords: Library, school library, culture, habit of reading.

ABSTRAK - Penelitian ini berjudul "Peranan Perpustakaan Sekolah Dalam Meningkatkan Budaya Gemar Membaca" (Studi Deskriptif tentang Peranan Perpustakaan Sekolah dalam Meningkatkan Budaya Gemar Membaca Siswa Madrasah Aliyah di Yayasan Pendidikan Islam Nurul Huda)" ini bertujuan untuk mengetahui peran perpustakaan yang terdiri dari empat komponen, yaitu pustakawan, koleksi, manajemen pengelolaan dan tata ruang dalam meningkatkan budaya gemar membaca siswa Madrasah Aliyah di Yayasan Pendidikan Islam Nurul Huda). Penelitian ini menggunakan metode deskriptif. Teknik pengumpulan data yang dilakukan adalah dengan cara menyebar angket, wawancara, observasi dan studi literatur. Hasil penelitian dapat dikatakan bahwa pustakawan di perpustakaan Yapinda Nurul Huda mempunyai peran dalam meningkat- kan budaya gemar membaca siswa, koleksi di perpustakaan Yapinda
Nurul Huda mempunyai peranan dalam meningkatkan budaya gemar membaca siswa, pengelolaan perpustakaan di perpustakaan Yapinda Nurul Huda mempunyai peranan dalam meningkatkan budaya gemar membaca siswa, dan tata ruang perpustakaan di perpustakaan Yapinda Nurul Huda mempunyai peranan dalam meningkatkan budaya gemar membaca siswa.

Kata Kunci: Perpustakaan, Perpustakaan Sekolah, Budaya, Gemar Membaca

\section{PENDAHULUAN}

Strategi promosi merupakan awal dalam rangka mengenalkan produk kepada konsumen dan ini menjadi sangat penting karena berhubungan dengan keuntungan-keuntungan yang akan diperoleh perusahaan. Strategi promosi akan bisa berguna dengan optimal bila didukung dengan perencanaan yang terstruktur dengan baik.

Dalam undang-undang Nomor 25 tahun 2000 tentang Program Pembangunan Nasional (PROPENAS) dijelaskan bahwa: "Perpustakaan merupakan sumber daya pendidikan yang penting dalam upaya meningkatkan kualitas Pendidikan Prasekolah, Pendidikan Dasar dan Menengah. Dalam upaya Renstra Pendidikan, Pemuda dan Olahraga Departemen Pendidikan Prasekolah, Pendidikan Dasar dan Pendidikan Menengah di antaranya adalah peningkatan penyediaan penggunaan dan perawatan sarana dan prasarana pendidikan, termasuk buku dan alat 
peraga pendidikan, perpustakaan dan laboratorium bagi sekolah negeri dan swasta secara bertahap" (Wahyudiati, diakses tanggal, 3 Desember 2013).

Dengan adanya undang-undang tersebut diharapkan ada peningkatan kualitas dalam dunia perpustakaan untuk semakin maju dan berkembang sehingga perpustakaan yang mampu melayani segala bentuk kebutuhan informasi yang dibutuhkan pengguna, terutama keberadaan perpustakaan yang ada di setiap lembaga pendidikan pun seyogyanya menjadi bagian yang tidak terpisahkan dengan dunia pendidikan.

Perpustakaan sebagai salah satu pusat informasi, dalam kacamata pendidikan peranannya cukup penting. Karena proses belajar mengajar dapat berjalan dengan efektif jika rujukannya tersedia. Melalui perpustakaan dengan sumber-sumber informasi yang ada didalamnya sedianya dapat membantu untuk meningkatkan mutu kualitas pendidikan dan output-nya kelak.

Dalam kehidupan yang serba modern dan cepat seperti saat ini semua orang membutuhkan informasi sebagai suatu hal yang hakiki. Tanpa informasi atau ketinggalan informasi akan membuat seseorang tersisih dan terbelakang. Peran perpustakaan menjadi nyata. Perpustakaan menjadi pusat informasi yang tidak pernah habisnya untuk digali, ditimba dan dikembangkan. Melalui perpustakaan seseorang dapat bertukar inforrnasi dan saling memperoleh nilai tambah untuk perkembangan zaman.

Undang-Undang No. 20 Tahun 2003 tentang Sistem Pendidikan Nasional, menyebutkan bahwa standar sarana prasarana pendidikan mencakup ruang belajar, tempat olah raga, tempat beribadah, perpustakaan, laboratorium, bengkel kerja, tempat bermain, tempat berkreasi dan sumber belajar lain yang diperlukan untuk menunjang proses pernbelajaran termasuk penggunaan teknologi infonnasi dan informasi. Jadi perpustakaan merupakan salah satu sumber belajar yang sangat penting untuk menunjang proses belajar mengajar.

Jika dikaitkan dengan proses belajar mengajar di Yayasan Pendidikan Islam (Yapinda) Nurul Huda, perpustakaan di sana memberikan sumbangan yang sangat berharga dalam upayanya meningkatkan minat baca siswa serta meningkatkan kualitas pendidikan dan pengajaran. Perpustakaan dapat memainkan peran, khususnya dalam membantu siswa untuk mencapai tujuan pendidikan. Dengan memanfaatan perpustakaan secara maksimal, siswa diharapkan terbiasa dengan aktifitas membaca, memahami pelajaran, mengerti maksud dari sebuah informasi dan ilmu pengetahuan, serta menghasilkan karya bermutu. Kebiasaan membaca buku yang dilakukan oleh siswa, akan meningkatkan pola pikirnya sehingga perlu dijadikan aktivitas kegiatan sehari-hari.

Perpustakaan sekolah dapat dijadikan sumber belajar siswa baik dalam proses kegiatan belajar mengajar secara formal maupun non formal untuk membantu sekolah dalam upaya mencapai tujuan pendidikan di sekolah tersebut. Pada kenyataannya, perpustakaan kurang mendapat tempat di lingkungan sendiri. Tidak banyak siswa yang memanfaatkan waktu luang atau jamjam kosong pelajaran untuk membaca di 
perpustakaan. Perpustakaan hanya dikunjungi dang selebihnya memilih memanfaatkan sarana lain untuk belajar. Hal ini menunjukkan kurangnya minat siswa dalam memanfaatkan koleksi perpustakaan sebagai sarana belajar.

Minat baca menurut Kamus Besar Bahasa Indonesia (2003: 583) memuat pengertian minat sebagai kecenderungan hati yang tinggi terhadap sesuatu, gairah atau keinginan. Sedangkan menurut Slameto (1995:180) minat adalah suatu rasa lebih suka dan rasa ketertarikan pada suatu hal atau aktifltas, tanpa ada yang menyuruh. Minat pada dasarnya adalah penerimaan akan suatu hubungan antara diri sendiri dengan suatu diluar diri. Semakin kuat atau dekat hubungan tersebut, semakin besar minat.

Berdasarkan pengertian diatas dapat dikatakan bahwa minat bukanlah tingkah laku, tetapi sesuatu yang mendorong timbulnya tingkah laku. Minat adalah karakteristik yang dipelajari, bukan diturunkan atau bawaan, namun diperoleh lewat interaksi dengan objek-obiek, orang atau sekelompok orang dalam situasi dan kejadiankejadian tertentu. Oleh karena dipelajari maka minat dapat diubah dan sangat mungkin berubah atau bahkan menghilang.

Minat baca juga demikian, sesuatu yang mampu mendorong timbulnya tingkah laku membaca pada seseorang. Dapat dibentuk, dapat berubah menguat, melemah atau batrkan hilang sama sekali. Di sinilah perpustakaan sekolah memiliki peran penting dalam memacu tercapainya tujuan pendidikan di sekolah. Dengan demikian perpustakaan merupakan suatu unit kerja dari sebuah lembaga yang berupa tempat oleh siswa yang memerlukan informasi saja, semenyimpan koleksi bahan pustaka penunjang proses pendidikan yang diatur secara sistematis.

Pada dasarnya, pihak sekolah beranggung jawab ikut menumbuhkan minat baca bagi siswa, karena dari sanalah sumber kreatifitas siswa akan muncul. Sekolah harus mengajar anak-anak berpikir melalui budaya belajar yang menekankan pada memahami materi. Sedangkan perpustakaan menjadi fasilitas yang sangat penting perannya dalam menunjang proses pembelajaran tersebut.

Hal ini terjadi pada perpustakaan di Yayasan Pendidikan Islam Nurul Huda yang berlokasi di Jalan KH. Wahid Hasyim (Kopo) Gg. Parasdi I No. 7 Bandung, Jawa Barat. Sebuah sekolah swasta yang, yang keberadaannya menjorok masuk gang, dan memiliki perpustakaan yang koleksinya seadanya, fasilitas yang kurang walaupun dikelola dengan cukup baik. Perpustakaan sekolah tersebut berusaha untuk memberikan kenyamanan kepada siswasiswanya, agar mereka merasa nyaman untuk membaca koleksi yang tersedia di perpustakaan sekolah tersebut. Dengan harapan, walaupun keadaan perpustakaan minimalis, dapat menghasilkan siswa yang berprestasi maksimalis (Wawancara dengan Iip Saprudin, tanggal 4 Desember 2013).

Sebuah perpustakaan yang menarik bagi pengguna, secara tidak langsung itu dapat merangsang mereka untuk berkunjung kembali ke perpustakaan tersebut, sehingga dapat berdampak dapat menghasilkan dan meningkatkan minat baca siswa. Dalam menumbuhkan minat baca dan 
membuktikan bahwa suatu perpustakaan tidak hanya sekedar tempat membaca tetapi sudah berkembang sebagai tempat siswa mengembangkan kemampuan dan bakatnya, serta adanya kebutuhan akan suatu kesempatan yang mengakomodasi keinginan siswa untuk menunjukkan kemampuan yang telah dilatih dan dikembangkan melalui perpustakaan.

Dalam konteks itulah diyakini bahwa minat baca mempengaruhi proses dan hasil belajar siswa. Tidak banyak yang dapat berharap untuk menghasilkan prestasi belajar yang baik dari seorang siswa yang tidak berminat untuk mempelajari sesuatu. Untuk memenuhi kebutuhan para siswanya dalam pencarian informasi, pihak sekolah berusaha untuk membuat perpustakaan yang ideal dengan tujuan untuk meningkatkan minat baca santrinya.

Dari uraian di atas, maka penulis tertarik untuk mengadakan penelitian dengan judul: "Peran Perpustakaan dalam Meningkatkan Budaya Gemar Membaca Siswa di Yayasan Pendidikan Islam Nurul Huda Bandung”.

\section{TINJAUAN PUSTAKA}

Perpustakaan adalah sebuah ruangan atau gedung yang digunakan untuk menyimpan buku dan terbitan lainnya yang biasanya disimpan menurut tata susunan tertentu yang digunakan pembaca bukan untuk dijual (Sulistyo-Basuki, 1991:3).

Kehadiran perpustakaan bukanlah hal yang baru di kalangan masyarakat. Dimana-mana telah diselenggarakan perpustakaan seperti sekolah baik umum maupun kejuruan. Keberadaan perpustakaan adalah untuk menunjang sarana belajar mengajar.

Menurut Darmono (2011:1-2), hakikat perpustakaan sekolah adalah pusat atau sumber belajar dan sumber informasi bagi pemakainya (anak didik). Perpustakaan juga berfungsi sebagai rekreasi untuk menunjang hobi dan imajinasi pengunjung. Perpustakaan juga bermanfaat sebagai pusat penelitian yang berarti perpustakaan sebagai lembaga yang turut menunjang kegiatan riset yang terkait dan tersedia di perpustakaan, dan terakhir adalah fungsi deposit yang berarti fungsi menyimpan dan melestarikan semua karya cetak dan karya rekam. Namun masih sedikit sekali yang memiliki kesadaran akan arti pentingnya membaca, hal ini disebabkan karena beberapa kendala yaitu kurangnya sarana perpustakaan sekolah yang berakibat pada rendahnya pertumbuhan minat baca siswa dan guru yang akhirnya menghambat tumbuh kem- bangnya pola pikir kritis siswa sebagai model bagi terciptanya kondisi berfikir ilmiah di lingkungan sekolah (Hermawan, 2003:3).

Perpustakaan memiliki peranan yang sangat penting untuk meningkatkan minat baca anak didiknya. Ada beberapa hal tentang perpustakaan yang dapat mempengaruhi minat baca siswa, pertama, ketika sebuah perpustakaan memiliki koleksi yang lengkap, para pengguna informasi akan merasa puas karena informasi yang mereka cari bisa mereka temukan di perpustakaan tersebut. Ketika mereka merasa puas, tidak menutup kemungkinan para pengguna informasi akan datang lagi dan mencari informasi yang 
lainnya. Kedua, sumber daya manusia yang mengelola perpustakaan juga memiliki peran besar dalam pengaruh minat baca terhadap para pengguna informasi,

Ketiga, adalah manajemen pengelolaan perpustakaan, namun manajemen ini tergantung bagaimana sumber daya manusia yang mengelolanya. Bagaimana sumber daya manusia memajukan sebuah perpustakaan, bagaimana para pengguna mudah untuk menemukan informasi atau koleksi yang mereka butuhkan itu menjadi manajemen perpustakaan yang berdampak kepada kepuasan para pengguna informasi.

Keempat, adalah tata ruang, dalam hal ini bagaimana perpustakaan memberikan kenyamanan kepada para pengguna informasi untuk membaca dan betah untuk berlama-lama di perpustakaan tersebut.

Semua kondisi di atas, tentunya akan menimbulkan minat baca pada siswa, pada dasarnya minat dan kebiasaan membaca merupakan keterampilan yang diperoleh setelah seseorang dilahirkan dan bukan merupakan keterampilan bawaan, melainkan perlu dipupuk, dibina, dan dikembangkan. Minat dan kegemaran membaca tidak dengan sendirinya dimiliki seseorang, termasuk anak-anak dalam usia sekolah. Minat baca dapat tumbuh dan berkembang dengan cara berbentuk. Dengan demikian diharapkan dari gemar membaca akan meningkat menjadi memiliki jiwa baca, lalu muncul kebiasaan membaca. Selain itu peningkatan gemar membaca harus didukung oleh jumlah dan mutu kinerja perpustakaan yang harus ditingkatkan (Media Pustakawan, 1996:4).
Lilawati (dalam Sandjaja, 2005) mengartikan minat baca adalah suatu perhatian yang kuat dan mendalam disertai dengan perasaan senang terhadap kegiatan membaca sehingga dapat mengarahkan seseorang untuk membaca dengan kemauannya sendiri. Minat membaca adalah sumber motivasi kuat bagi seseorang untuk menganalisa dan mengingat serta mengevaluasi bacaan yang telah dibacanya, yang merupakan pengalaman belajar menggembirakan dan akan mempangaruhi bentuk serta intensitas seseorang dalam mencapai cita-citanya kelak di masa yang akan datang, hal tersebut juga adalah bagian dari pengembangan diri yang harus senantiasa diasah sebab minat baca tidak diperoleh dari lahir.

Fungsi utama perpustakaan adalah untuk membangkitkan dan meningkatkan minat baca siswa yang dilayaninya (pemustaka). Dengan program-program yang dibuatnya, perpustakaan menjadi pelopor dalam menarik minat siswa supaya dekat dengan sumber informasi. Dan pustakawan berperan sebagai agen perubahan untuk menciptakan siswa membaca (reading society) sebagai salah satu pilar utama menuju siswa belajar (learning society). Walaupun kesan yang ada sekarang ini adalah perpustakan dan pustakawan hanya berperan sebagai pelayan saja bagi kebutuhan informasi siswa, sejatinya para pustakawanlah yang mengadakan pelatihanpelatihan atau berbagai macam program dan juga berinisiatif untuk menulis literatur yang dapat membangkitkan semangat membaca siswa, karena ia setiap hari bergulat dengan sumber informasi, di samping itu juga karena pustakawanlah yang paling dekat dengan para pemustaka.

Penjelasan di atas menerangkan bahwa 
timbulnya selera membaca disebabkan oleh adanya koleksi yang beragam dan variatif. Selanjutnya selera membaca ini akan menimbulkan minat baca, yang kalau diulang terusmenerus dan menghasilkan kebiasaan membaca. Dan kebiasaan membaca ini akan menjadi landasan dari pengembangan koleksi. Dari pola seperti di atas dapat terlihat bahwa ada korelasi yang sangat kuat antara koleksi dengan kebiasaan membaca. Faktor utama untuk menum- buhkan minat baca adalah koleksi.

Dengan kata lain para siswa akan memutuskan apakah mereka akan membaca atau tidak setelah mereka merasa nyaman dan puas dengan apa yang ditawarkan oleh perpustakaan yang berakibat timbulnya minat baca pada siswa.

\section{METODE PENELITIAN}

Dalam penelitian ini, metode penelitian yang digunakan adalah deskriptif. Metode deskriptif adalah metode penelitian yang bertujuan untuk menggambarkan suatu keadaan yang sementara berjalan pada saat penelitian dilakukan dengan mengambil sampel dari suatu populasi dan menggunakan kuisioner sebagai alat pengumpulan data pokok. Dengan metode deskriptif ini, diharapkan akan mendapatkan gambaran yang tepat mengenai peran perpustakaan dalam meningkatkan budaya gemar membaca siswa. Sedangkan untuk menggambarkan yang diteliti, digunakan dua jenis data yakni data primer dan data sekunder. Data primer bersurnber langsung dari responden penelitian dari pihak-pihak yang relevan, sedangkan data sekunder bersumber pada dokumentasi serta referensi-referensi yarg relevan.
Adapun metode pengumpulan data dalam penelitian ini adalah sebagai berikut:

1. Angket. Digunakan untuk memperoleh data primer, yaitu dengan cara mengumpulkan data yang diperoleh dari responden dengan menggunakan daftar pertanyaan.

2. Observasi. Melakukan pengamatan langsung kepada objek penelitian langsung untuk memperoleh data yang dibutuhkan langsung.

3. Wawancara. Pengumpulan data melalui komunikasi dan tatap muka langsung dengan responden.

4. Studi Pustaka. Pencarian data-data penunjang untuk memperoleh rujukan teoritis yang berkaitan dengan masalah yang diteliti melalui bahan pustaka.

Untuk menentukan responden sebagai sumber utama data primer, maka populasi dalam penelitian ini adalah siswa Madrasah Aliyah yang bersekolah di Yayasan Pendidikan Islam Nurul Huda yang berjumlah 170 orang. Populasi adalah jumlah keseluruhan dari unit analisa yang ciricirinya akan diduga (Singarimbun: 1989).

Sampel adalah bagian dari populasi yang akan dipelajari dan diamati untuk diteliti dan dianggap dapat menggambarkan populasinya (Rakhmat, 2001: 78). Sampel dimaksudkan untuk menggambarkan suatu populasi.

Untuk menentukan jumlah sampel dalam penelitian ini digunakan rumus Slovin dengan tingkat presisi $\pm 8 \%$ dan tingkat kepercayaan \pm 92\%. Pada penelitian ini penulis menggunakan 
stratified random sampling untuk mengambil sampel awal dari populasi yang ada.

Teknik analisis data penelitian yang digunakan dalam penelitian ini adalah satistik deskriptif. Analisis ini digunkan untuk mendeskripsikan dan menggambarkan data yang terkumpul untuk umum atau generalisasi (Sugiyono, 2012:172). Teknik ini memaparkan jawaban responden dalam bentuk tabel frekuensi den presentase. Tabel-tabel tersebut selanjutnya disertai interpretasi penulis untuk mengetahui makna dari data-data penelitian tersebut.

Perhitungan presentase dalam tabel frekuensi dihitung berdasarkan rumus: $\mathrm{P}=\mathrm{f} / \mathrm{n} \times 100 \%$, di mana $\mathrm{P}=$ Presentase frekuensi, $\mathrm{f}=$ Frekuensi kelas dan $\mathrm{n}=$ Ukuran sampel. Lokasi penelitian ini dilakukan di perpustakaan sekolah milik Yayasan Pendidikan Islam Nurul Huda Bandung.

\section{HASIL DAN PEMBAHASAN}

Dari hasil penelitian yang telah dilakukan, mengenai Peran Perpustakaan dalam Meningkatkan Budaya Gemar Membaca Siswa di Yayasan Pendidikan Islam Nurul Huda Bandung, dapat ditarik simpulan sebagai berikut:

1) Berdasarkan hasil penelitian, dapat diketahui bahwa Pustakawan mempunyai peran di perpustakaan Yapinda Nurul Huda dalam meningkatkan budaya gemar membaca siswa. Hal ini terlihat dari jawaban responden yang menyatakan setuju bahkan sangat setuju bahwa pengelola perpustakaan Yapinda Nurul Huda selalu memberikan senyum dalam melayani penggunanya, selain itu pengelola perpustakaan juga selalu bernampilan menarik dan rapih, membantu pengguna jika mengalami kesulitan saat mencari buku, memberikan informasi dengan akurat, menguasai pengetahuan yang luas yang menunjang dalam memberikan pelayanan kepada pengguna, Selain itu, pengelola perpustakaan Yapinda Nurul Huda juga selalu berinisiatif membantu para pengguna informasi.

2) Berdasarkan hasil penelitian, dapat diketahui bahwa koleksi di perpustakaan Yapinda Nurul Huda mempunyai peranan dalam meningkatkan budaya gemar membaca siswa. Hal ini terlihat dari koleksi buku yang terdapat di perpustakaan Yapinda Nurul Huda sesuai dengan kebutuhan siswa; perpustakaan Yapinda menyediakan buku atau koleksi terbatas, Perpustakaan Yapinda Nurul Huda menyediakan buku-buku terbaru (up to date), para responden mendapatkan pengetahuan yang baru, Perpustakaan Yayasan Pendidikan Islam Nurul Huda tidak menyediakan koleksi yang berbentuk elektronik (seperti: audio, visual, dan audio visual) namun mereka menyediakna komputer sebagai sarana penggantinya. Selain buku, perpustakaan Yapinda Nurul Huda menyediakan koleksi berbentuk cetak lainnya (seperti majalah, novel, koran).

3) Berdasarkan hasil penelitian, dapat diketahui bahwa pengelolaan perpustakaan di perpustakaan Yapinda Nurul Huda mempunyai peranan dalam 
meningkatkan budaya gemar membaca siswa. Hal ini berdasarkan bahwa, perpustakaan Yapinda Nurul Huda mengadakan kegiatan yang menarik tiap tahunnya dan perpustakaan Yapinda Nurul Huda konsisten menyelenggarakan kegiatan setiap tahunnya.

4) Berdasarkan hasil penelitian, dapat diketahui bahwa tata ruang perpustakaan di perpustakaan Yapinda Nurul Huda mempunyai peranan dalam meningkatkan budaya gemar membaca siswa. Hal ini dapat dilihat dari ruang perpustakaan Yayasan Pendidikan Islam Nurul Huda berada pada posisi yang strategis, mempunyai ventilasi udara yang baik, pengguna mendapatkan kenyamanan saat berada di ruang baca, pengguna mendapatkan kenyamanan saat berada di ruang sirkulasi, pengguna mendapatkan kenyamanan saat berada di ruang komputer, perpustakaan Yapinda Nurul Huda mempunyai penerangan (lampu) yang baik, dan walaupun perpustakaan Yayasan Pendidikan Islam Nurul Huda tidak dapat menampung banyak pengunjung.

\section{SIMPULAN}

Berdasarkan pembahasan yang telah dipaparkan di atas, dapat disimpulkan sebagai berikut:

1. Perpustakaan Yapinda Nurul Huda menyediakan koleksi buku yang lebih up to date (cetakan terbaru dan tahun terbit yang aktual), sehingga koleksi yang dimiliki perpustakaan Yapinda Nurul Huda selain beragam, juga sesuai/relevan dengan kebutuhan informasi siswa;

2. Perpustakaan menambah koleksi buku terutama buku-buku umum jenis karya fiksi dan juga menyediakan koleksi audio visual dengan terbaru;

3. Perpustakaan Yapinda Nurul Huda sebaiknya lebih meningkatkan kualitas sarana dan prasarana berbasis teknologi yang lebih lengkap dan mutakhir, yaitu menambah kecepatan akses internet dan pengalihan proses penelusuran bahan pustaka manual ke bentuk digital (komputerisasi), agar mempermudah siswa mengakses informasi;

4. Siswa menilai staf perpustakaan memiliki pengetahuan dan wawasan yang cukup luas, tetapi siswa merasa belum mengenal betul staf perpustakaan. Untuk itu sebaiknya staf lebih banyak berinteraksi dengan siswa melalui komunikasi secara aktif untuk membantu siswa memperoleh informasi yang dibutuhkan.

\section{DAFTAR PUSTAKA}

Darmono, (2011). Manajemen dan Tata Kerja Perpustakaan Sekolah. PT. Grasindo, Jakarta.

Departemen Pendidikan Nasional, Pusat Bahasa.

(2003). Kamus Bahasa Indonesia. Jakarta.

Departemen Pendidikan Nasional RI. (2005). Pedoman Perpustakaan 
Perguruan Tinggi, Jakarta: Departemen tanggal 28 November 2013

Pendidikan Nasional RI Direktorat melalui situs

Jendral Pendidikan Tinggi.

Hermawan, Iwan. (2003). "Potret

Perpustakaan Dewasa Ini", Berita Pikiran

Rakyat On-Line, 11 Juni (2003), h.3.

Media Pustakawan, 1996.

Qalyuby, Shihabuddin (ed.), (2003).

Dasar-dasar Ilmu Perpustakaan dan

Informasi. Yogyakarta Jur. IPII, Fak.

Adab IAIN Sunan Kalijaga Yogyakarta

Rakhmat, Jalaluddin. (2001). Psikologi

Komunikasi. PT. Remaja Rosdakarya.

Bandung.

Singarimbun, Masri. (1989). Metode

Penelitian Survai. Jakarta: LPS3ES

Sandjaja, B., dan Heriyanto. A., (2006). Panduan

Penelitian,

Prestasi Pustaka. Jakarta

Slameto. (1995). Belajar dan faktor-

faktor Yang Mempengaruhinya, PT.

Rineka Cipta. Jakarta.

Sugiyono, (2012), Metode Penelitian

Kuantitatif, Kualitatif dan $R \& D$, Alfabeta,

Bandung

Sulistyo-Basuki, (1991). Pengantar Ilmu

Perpustakaan. Jakarta: Gramedia Pustaka

Utama

Undang-undang No. 20 tahun (2003),

tentang Sistem Pendidikan Nasional

(http://pcucamel.petra.ac.id/downloadf

ile.php?id=89, diakses tanggal, 25

Januari 2014)

Wahyudiati. "Optimalisasi Perpustakaan Sekolah Untuk Menumbuhkan Minat Baca". Artikel ini diakses 
